\title{
The Utilization of Jamu Waste as a Biofertilizer Material for Making Organic Fertilizer in Rukun Makaryo Farmers Group
}

\author{
Catur Rini Sulistyaningsih ${ }^{1 a^{*}}$, Catur Budi Handayani ${ }^{1}$ \\ Faculty of Agriculture, Veteran Bangun Nusantara University of Sukoharjo, Indonesia \\ Email : caturrinisulistyaningsih@gmail.com \\ ${ }^{*}$ Corresponding Author \\ Whatsapp Number [081329383787]
}

How to Cite: Sulistyaningsih C R.,\& Handayani C B. (2020). The Utilization of Jamu Waste As A Biofertilizer Material For Making Organic Fertilizer In Rukun Makaryo Farmers Group. International Journal for Educational and Vocational Studies, 2(2), 201-204. DOI: https://doi.org/10.29103/ijevs.v2i2.2329

\section{ARTICLE HISTORY}

Received: 21 November 2019

Revised: 20 January 2020

Accepted: 8 February 2020

\section{KEYWORDS}

Herbal Medicine Waste;

Organic Fertilizer;

Rukun Makaryo Farmer Group:

\section{ABSTRACT}

The Community Partnership Program aims to handle livestock waste, namely the making of starter-mol (biofertilizer) based on herbal waste as well as biological fertilizer and the manufacture of solid organic fertilizer based on solid manure (feces) and cattle feed residues. The target of the Community Partnership Program is to reduce waste pollution, especially herbal medicine waste, increase the added value of herbal waste that can be used as a source of microorganisms in making starter-mol (biofertilizer), increase knowledge about making biofertilizers and quality organic fertilizers, produce quality organic fertilizers in order to fulfil the fertilizer needs of Rukun Makaryo farmer group. Increasing the yield of organic rice produced by Rukun Makaryo farmer groups. The method is done by counseling with lectures, discussions, through training with direct practice by partners, mentoring to partners and evaluation. The 38 participants who followed the pretest-posttest and $57.63 \%$ improved understanding so that training and extension activities have reached an indicator of successLaboratory analysis results on the content of macroelements $(N, P, K)$, organic $C$, organic matter and $C$ / N Ratio following fertilizer quality standards from Menpen (Compost Standardization No: 28/ Permentan/ SR.130 / 5/2009, May 22, 2009 and 2005.

This is an open access article under the CC-BY-SA license.

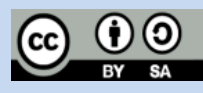

\section{INTRODUCTION}

Livestock waste is waste from a livestock business activity such as livestock raising, slaughterhouses, processing of livestock products, and so on. These wastes include solid waste and liquid waste such as feces, urine, food scraps, embryos, eggshells, fat, blood, fur, nails, bones, horns, rumen contents, etc. (Sihombing, 2000). As the livestock business grows, the waste produced increases. The total waste produced by livestock depends on livestock species, size of the business, type of business and floor of the cage. Cow manure consisting of stool and urine is the most produced livestock waste and most of the manure is produced by ruminants such as cattle, buffalo goats, and sheep. Generally, every kilogram of milk produced by dairy cattle produces $2 \mathrm{~kg}$ of solid waste (feces), and every kilogram of beef produces $25 \mathrm{~kg}$ of feces (Sihombing, 2000). According to Soehadji (1992), livestock waste includes all the waste produced from a livestock business activity in the form of solid waste and liquid, gas, and food waste. Solid waste is all solid waste or solid phase (livestock manure, dead cattle, or stomach contents from cattle slaughter). Liquid waste is all liquid waste or liquid phase (urine or urine, water from washing tools). While waste gas is all gaseous waste or in the gas phase.

Pollution because methane gas causes an unpleasant odor to the surrounding environment. Methane gas $(\mathrm{CH} 4)$ comes from the digestion process of ruminants. This methane gas is one of the gases responsible for global warming and ozone destruction, at a rate of $1 \%$ per year and continues to increase. Apppalagi in Indonesia, methane emissions per unit of feed or methane conversion rate is greater because the quality of forage given is low.The higher the amount of low quality feed, the higher the production of methane (Suryahadi et al., 2002). Livestock waste still contains nutrients or solids that have the potential to encourage the life of microorganisms that can cause pollution. A study of water pollution by livestock waste reported that a total of 5,000 $\mathrm{kg}$ of cattle for one day, the manure production could contaminate 9,084 x 107 m3air. Besides through water, livestock waste often pollutes the biological environment, namely as a medium for the breeding of flies. The water content of manure between $27-86 \%$ is the best medium for 
the growth and development of fly larvae, while the content of manure water from 65 to $85 \%$ is the optimal medium for laying flies. The presence of livestock waste in dry conditions can cause pollution, namely by causing dust. Air pollution in the most cattle fattening environment is around 18:00, the dust content at that time is more than $6000 \mathrm{mg} / \mathrm{m} 3$, so it has exceeded the threshold that can be tolerated for air freshness in the environment (3000 mg / m3) One result of pollution water by waste ruminants is increased nitrogen levels. Nitrogen compounds as pollutants have a specific pollution effect, where their presence can cause consequences of decreasing water quality as a result of the process eutrophication, a decrease in dissolved oxygen concentration as a result of the nitrification process that occurs in water which can result in disruption of the life of aquatic biota (Farida, 1978). These problems need to be addressed and given a solution. Several things can be done in this farmer group in the context of handling livestock waste, namely making rumen-based mole starter livestock as well as biofertilizers and making solid organic fertilizer based on solid manure (feces) and remaining cattle feed plus chaff (waste rice).

\section{MATERIALS AND METHODS}

The solutions offered to overcome partner problems are as follows:

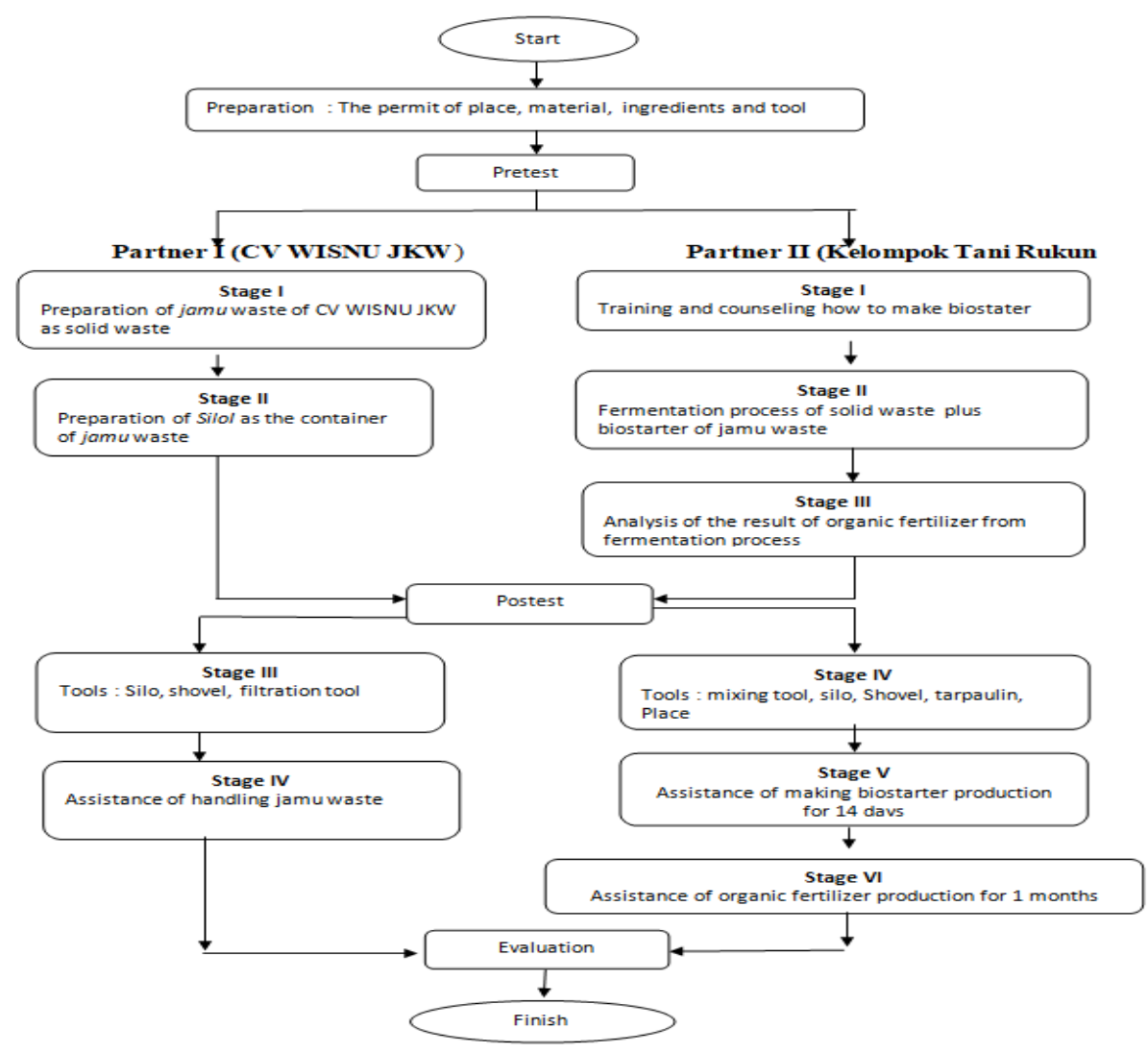

Figure 1. Flow chart of the method of Implementing the Community Partnership Program for Making CV JKW Organic Fertilizer (Joglo Krena Wisnu) and Rukun Makaryo Farmer Group

\section{Description :}

Stage I Making Biostarter:

1. Microbial preparation:

- The microbial ingredients and media used include rummino bacillus, sacharomyces cereviceae, azotobacter, sugar cane drops, protein media and herbal waste obtained from CV JKW's herbal waste storage (Krena Wisnu Joglo).

\section{Biostarter making:}

- After the microbial materials and the media to be used are ready, then the ingredients are mixed with a certain ratio and wait for the ripening process for 14 days with stirring every day every morning with an anaerobic process.

3. Executor: Bantara Agribusiness Study Program dedication team, Sukoharjo

(Ir. Catur Rini Sulistyaningsih, MM., And Ir. Catur Budi Handayani, MP) 
4. Partner participation: participation as a provider of infrastructure and materials.

Stage II Fermentation process of solid impurities and animal feed waste :

1. Preparing the material to be fermented is cow dung, dolomite, and the rest of the feed, then semi-aerobically fermented for 1 month by using a starter of microbes that have been tested in the sheet.

2. Objective: to obtain quality solid organic fertilizer that is ready to be applied in the field.

3. Executor: Bantara Univet Service Team Sukoharjo (Coordinator of Catur Rini Sulistyaningsih)

4. Partner participation: participation as active participants

Stage III. Analysis of organic fertilizer results from fermentation.

1. Do testing both micro and macro according to Compost No: 28/Permetan / SR.130/5 /2009,22 May 2009, and 2005 Fertilizer Standardization.

2. Objective: to know the nutritional content of fertilizers, nutrients contained in organic fertilizers are following standards.

3. Executor: Bantara Univet Service Team Sukoharjo (Coordinator of Catur Rini Sulistyaningsih)

4. Observation and implementation is carried out for 1 month

Partner participation: participation as active participants.

\section{RESULT and DISCUSSION}

The first activity carried out by the team was a coordination meeting held at the Veteran Bangun Nusantara University meeting room. The coordination meeting was attended by the head of the service team, the service team members, and 4 student research assistants. The next activity was coordination which was attended by the Rukun Makaryo Farmers Group, along with representatives of other farmer groups from Pereng Village, Mojogedang. The coordination meeting runs for approximately 90 minutes. The results of the Coordination Meeting are a discussion of the equipment and materials that will be used to make a starter/biofertilizer. The materials used will be provided by the Community Service team of Univet Bantara, Sukoharjo. The participants who will be invited to the training are planned to have around 50 farmers, who are involved in organic farming in the scope of Mojogedang Subdistrict and its surroundings. The Coordination Meeting running well and subsequently it was determined the Day and Date of the Starter/Biofetilizer Making Training.

The next stage is the purchase of equipment for service. The results of the coordination meeting with the rukun makaryo farmer groups, namely the tools needed were shovel silos, chillers, hoses, hose, buckets, bailers, sieves, plastic and bottles. The next preparation was held on April 10, 2019 coordinating with CV JKW (Joglo Krena Wisnu) who became a service partner.

The Community Service team has completed several stages according to the implementation method. The stages that have been implemented are as follows:

\section{Stage I. Making bio starter:}

Microbial preparation, Microbial materials and media used include rummino bacillus, sacharomyces cereviceae, azotobacter, molasses, protein media and the most important is the waste products from CV JKW (Joglo Krena Wisnu) in the form of herbal waste. Herbal medicine is used as a source of microbes. CV JKW (Joglo Krena Wisnu) is located on Jl. Nguter Station, RT 001/05, Nguter, Sukoharjo, Sukoharjo Regency, Central Java. Participants in the Training for Making Starter/Biofertilizer presenters consisted of administrators and members of the Rukun Makaryo farmer group along with representatives of other farmer groups around Mojogedang District. Also attended were Mojogedang Field Extension Officers and a service team and students of Veteran Bangun Nusantara University Sukoharjo. The results obtained by MOL (Local Microorganisms) are a collection of several micro-organisms that can be bred and serve as a "starter" in making compost, liquid fertilizer or animal feed. The addition of MOL into livestock concentrates in the fermentation process in digesting basal food ingredients (fermentative digestion) which will ultimately improve the quality of meat.

Making MOL starters. First, prepare the microbes, such as the prime battery, JLK2 (ginger, ginger, turmeric, and kaempferia galanga), root stimulants, nutrition, fruit stimulants, and so on. For 10-15 days filtered, the pulp can be mixed with solid organic fertilizer. The prime bacterial is a starter MOL (Local Microorganism). It is use according to needs.(Sulistyaningsih, 2012). The starter that has become brown and smells less stinging. The MOL starter has been closed in a barrel (silo) to be used as a bacterial brood during the manufacture of organic fertilizer. The resulting bio starter can be used as a starter material because the results of the total microbial growth analysis are still following the standard. Stage I was attended by the chairman and members of the service team along with 4 students who helped. Participation as a provider of infrastructure and materials. Attended by 38 members of the Rukun Makaryo farmer group.

\section{Stege II. The waste fermentation process becomes organic fertilizer:}

The aim to get a solid organic fertilizer which qualified are ready for application in the field. Participants in the Organic Fertilizer Making Training Activities consisted of administrators and members of the Rukun Makaryo farmer group and residents of Pereng Village, Mojogedang who owned Organic Farming land. This activity attended by Rukun Makaryo farmer groups and a Community Service team from Veteran Bangun Nusantara University 
Sukoharjo and 4 students. The Organic Fertilizer Materials 1) Livestock manure (cow) 1 ton, 2) Katul $20 \mathrm{~kg}$, 3) Rice husk/peat 10 sacks, 4) Prime bacteria/starter 2 litres, 5) Sugar cane/mollases 2 litres, 6) 2 litres of JLK2 Cane drops function for additional nutrients for microbes so that they can accelerate the fermentation process and can increase the nitrogen content in fertilizers. Steps: Livestock / cow manure, husk and bran are stirred until evenly distributed. Prime bacterial, mollase and JLK2 are leaked and added enough water to be evenly distributed. Closed with a tarpaulin 2 weeks after being reversed, the temperature was checked 1 week and a 1 month reversal of fertilizer was made. Organic fertilizers from the farmer group Rukun Makaryo are cold, crumbly, the original form is not visible, the smell is not so stinging following the standards of the prepared fertilizer criteria.

\section{Stage III Analysis of organic fertilizer from fermentation:}

The purpose of the analysis is to find out the nutrient content of fertilizers, the nutrients contained in organic fertilizers are following standards, then whether micro or macro tests are carried out according to Compost No: 28/Permetan/SR.130/5/2009, May, 22 2009, and 2005. Analysis of organic fertilizer in the analysis process.

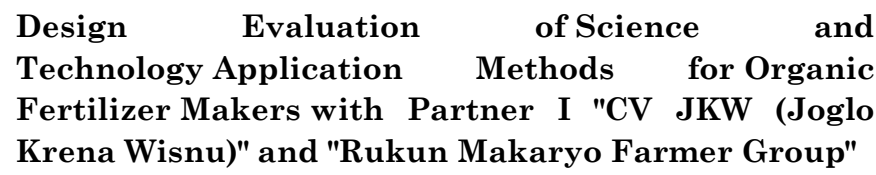

Before starting counseling and training for the members of the Rukun Makaryo group, they had to take the pretest first, after the counseling was finished, the participants were tested to work on the posttest. Evaluation indicators of the success of counseling and training as a herbal waste material organic biofertilizer in farmers' groups in Rukun Makaryo what if the post test scores have increased $\geq 25 \%$ of the pretests cores. Of the 38 participants who participated in the posttest and pretest can conclude that the increase of understanding is $57.63 \%$, the training and counseling activities achieved indicators of success.

Laboratory analysis results on the content of macroelements (N, P, K), organic C, organic matter and $\mathrm{C} / \mathrm{N}$ Ratio following fertilizer quality standards from Menpen (Compost Standardization No: 28/ Permentan/ SR.130/5/ 2009, May 22, 2009 and 2005.

\section{CONCLUSION}

The target of the Community Partnership Program is to reduce waste pollution, especially herbal medicine waste, increase the added value of herbal waste that can be used as a source of microorganisms in making starter-mol (biofertilizer), increase knowledge about making biofertilizers and quality organic fertilizers, produce quality organic fertilizers in order to fulfil the fertilizer needs of Rukun Makaryo farmer group. Increasing the yield of organic rice produced by Rukun Makaryo farmer groups. The method is done by counseling with lectures, discussions, through training with direct practice by partners, mentoring to partners and evaluation. The 38 participants who followed the pretest-posttest and 57.63\% improved understanding so that training and extension activities have reached an indicator of successLaboratory analysis results on the content of macroelements $(\mathrm{N}, \mathrm{P}, \mathrm{K})$, organic $\mathrm{C}$, organic matter and $\mathrm{C} / \mathrm{N}$ Ratio following fertilizer quality standards from Menpen (Compost Standardization No: 28/Permentan /SR.130/5/2009, May 22, 2009 and 2005.

\section{REFERENCES}

Catur Rini, Catur Budi. (2013). IbM CV.Agrobiz Abadi Jaya Di Gondangrejo, Karanganyar. Laporan Ipteks Bagi Masyarakat. Univet Bantara Sukoharjo

Catur Rini, Catur Budi, (2014). Produksi Pupuk Organik Anaerob Dengan Penambahan Biofertilizer Dan Uji Kompatibilitas Bibit Tanaman Pangan dan Holtikultura. Laporan Penelitian Hibah Bersaing. Univet Bantara Sukoharjo

Catur Rini, Nugraheni, Sri Harsono. (2016). Penentuan Pemakaian Dosis dan Macam Biofertilizer Dalam Pembuatan Pupuk Organik Padat Terhadap Kandungan Unsur Makro dan Mikro Nutrien Serta Logam Berat. Laporan Akhir Penelitian Hibah Bersaing. Univet Bantara Sukoharjo

Farida E. (2000). Pengaruh Penggunaan Feses Sapi dan Campuran Limbah Organik Lain Sebagai Pakan atau Media Produksi Kokon dan Biomassa Cacing Tanah Eisenia foetida savigry. Skripsi Jurusan Ilmu Nutrisi dan Makanan Ternak. IPB, Bogor.

Henry K. Indranada. (1986). Pengelolaan Kesuburan Tanah. Bina Aksara. Semarang.

Rinsema. (1986). Pupuk dan Pemupukan. Bharata Karya Aksara. Jakarta.

Sudarmi, Nugraheni, Catur Rini, Yos Wahyu. (2010). Iptek Bagi Masyarakat Kelompok tani Pembuatan Pupuk Organik dari Limbah Jerami di Kelurahan Begajah Kec/Kab Sukoharjo. Laporan Pengabdian kepada Masyarakat. Univet Bantara Sukoharjo

Sihombing. (2000). Teknik Pengelolaan Limbah Kegiatan/Usaha Peternakan.Pusat Penelitian Lingkungan Hidup Lembaga Penelitian. Institut Pertanian Bogor. Bogor.

Soehadji. (1992). Kebijaksanaan Pemerintah dalam Pengembangan Industri Peternakan dan Penangan Limbah Peternakan. Direktorat Jenderal Peternakan Departemen Pertanian. Jakarta. 